\title{
PERIZINAN BERUSAHA DI SEKTOR HULU MINYAK DAN GAS BUMI: EVALUASI SISTEM TERINTEGRASI SECARA ELEKTRONIK
}

\author{
Didik Sasono Setyadi ${ }^{1}$, Mailinda Eka Yuniza ${ }^{2}$ \\ ${ }^{1}$ Ilmu Pemerintahan, Institut Pemerintahan Dalam Negeri, Jatinangor \\ ${ }^{2}$ Fakultas Hukum, Universitas Gadjah Mada, Yogyakarta \\ mailinda@ugm.ac.id
}

\begin{abstract}
Abstrak
Penelitian ini bertujuan untuk mengevaluasi kesesuaian sistem perizinan berusaha terintegrasi secara elektronik terhadap sektor hulu minyak dan gas bumi (migas), baik sebelum maupun setelah berlakunya Undang-Undang Cipta Kerja. Kegiatan usaha hulu migas merupakan kegiatan pemerintah yang sangat penting bagi bangsa dan negara. Oleh karena itu, minimnya kegiatan eksplorasi yang salah satunya disebabkan oleh rumitnya perizinan, harus segera diselesaikan. Terkait hal tersebut, pemerintah mengeluarkan Peraturan Pemerintah Nomor 24 Tahun 2018 tentang Pelayanan Perizinan Berusaha Terintegrasi Secara Elektronik (PP 24/2018). Tulisan ini menggambarkan karakteristik Usaha Hulu Migas, melakukan inventarisasi dan mapping perizinan di sektor hulu migas setelah diperlakukannya PP 24/2018, melakukan evaluasi dan analisis kesesuaian PP 24/2018 dengan kebutuhan kegiatan hulu minyak dan gas bumi, serta memberikan rekomendasi untuk memperbaiki perizinan migas kedepan. Rekomendasi yang diberikan masih tetap relevan meskipun pemerintah telah mengeluarkan UU Nomor 11 Tahun 2020 Tentang Cipta Kerja dan Peraturan pelaksanaannya. Tidak banyak tulisan mengenai kegiatan hulu migas khusunya dari aspek hukum apalagi mengenai perizinan, termasuk penelitian ini. Metode yang digunakan adalah metode penelitian normatif, yaitu data yang utama digunakan adalah data sekunder yang diperoleh melalui studi pustaka. Adapun hasil penelitian ini menunjukkan bahwa: 1) kegiatan hulu migas memiliki karakteristik yang berbeda dan spesifik dibandingkan kegiatan usaha lainnya, 2) untuk mendukung sistem OSS sebagaimana diatur dalam PP 24/2018, pada awal tahun 2020 SKK Migas membentuk One Door Service Policy (ODSP), 3) Sistem Pelayanan Perizinan Terintegrasi Secara Elektronik (OSS) tidak sesuai dengan kebutuhan dan karakter kegiatan usaha hulu minyak dan gas bumi, sehingga OSS tidak bisa diharapkan untuk menjadi solusi bagi penyelesaian kerumitan perizinan Kegiatan Usaha Hulu Minyak dan Gas Bumi. Oleh karena itu, penulis mengusulkan agar Pemerintah mengeluarkan Peraturan Presiden yang dapat mengakomodir kondisi khusus hulu migas, menyederhanakan perizinan hulu migas secara menyeluruh dan memperkuat ODSP.
\end{abstract}

Kata kunci: Kegiatan Hulu Minyak dan Gas Bumi; Perizinan Berusaha Terintegrasi

\footnotetext{
1 Mahasiswa Program Doktoral Ilmu Pemerintahan Institut Pemerintahan Dalam Negeri (IPDN), Pengamat Hukum dan Kebijakan Publik.

2 Dosen Hukum Administrasi Negara Fakultas Hukum UGM dan Peneliti Pusat Study Energi UGM, email: mailinda@ugm.ac.id
} 


\title{
BUSINESS LICENSING IN THE UPSTREAM OIL AND GAS SECTOR: ELECTRONICALLY INTEGRATED SYSTEM EVALUATION
}

\begin{abstract}
Upstream oil and gas (oil and gas) business activities are vital for the nation and state. Therefore, the lack of exploration activities caused by the complexity of licensing must be resolved immediately. The government then issued Government Regulation Number 24 of 2018 concerning Integrated Business Licensing Services Electronically (GR 24/2018). This paper describes the specific Upstream Oil and Gas Business characteristics and compares the suitability of Government Regulation 24/2018 with the specific condition of the upstream oil and gas. Furthermore, this study provides recommendations for improving licensing of oil and gas in the future. Even though there is a Job Creation Law (Law No 11/2020) and its implementing rules, these recommendations are still relevant. The method used is the normative research method. The primary data used is secondary data obtained through a literature study. The results of this study indicate that: 1) upstream oil and gas activities have different and specific characteristics compared to other business activities, 2) to support the OSS system as regulated in PP 24/2018, in early 2020, SKK Migas established a One Door Service Policy (ODSP), 3) The Electronically Integrated Licensing Service System (OSS) does not work by the needs and character of the upstream oil and gas business activities. This study recommends that the government issue a Presidential Regulation that can accommodate special conditions in the upstream oil and gas, simplify licensing in upstream oil and gas entirely, and strengthen the position of ODSP.
\end{abstract}

Keywords: Upstream Oil and Gas; Online Single Submission

\section{PENDAHULUAN}

\section{A. Latar Belakang}

Kegiatan usaha hulu minyak dan gas bumi (migas) hingga saat ini masih merupakan kegiatan pemerintah yang sangat penting bagi bangsa dan negara. ${ }^{3}$ Paling tidak ada tiga alasan yang menyebabkan hal tersebut: migas penting untuk menjaga ketersediaan energi, migas memberikan kontribusi bagi penerimaan negara, serta migas mendorong perekonomian di sektor-sektor yang lain. ${ }^{4}$

Penting dan strategisnya migas menjadikan penurunan produksi migas sebagai persoalan nasional yang sangat urgent untuk segera diselesaikan. Hal ini

\footnotetext{
3 Satuan Kerja Khusus Pelaksana Kegiatan Usaha Hulu Minyak dan Gas Bumi, "Alur Bisnis Migas," Humas SKK Migas, 2016, https://humasskkmigas.wordpress.com/2016/07/27/alur-bisnis-migas.

4 "Konsideran huruf b Undang-Undang Nomor 22 Tahun 2001 Tentang Minyak dan Gas Bumi" (2001).
} 
mengingat semakin hari kebutuhan akan migas terus meningkat sementara produksinya terus menurun. Untuk minyak bumi, meskipun sebelumnya Indonesia pernah menjadi salah satu negara pengekspor minyak, sejak tahun 2003 Indonesia resmi menjadi nett importer yang berarti konsumsi minyak lebih besar dari produksinya. ${ }^{5}$ Data SKK Migas menunjukkan pada tahun 2020 produksi minyak dan kondensat nasional mencapai 708,5 ribu barel minyak per hari (Mbopd). Angka tersebut mengalami penurunan sebesar 36,6 Mbopd dibandingkan pencapaian produksi pada tahun 2019 sebesar 745,1 Mbopd. ${ }^{6}$

Terbalik dari sumber energi yang terus menurun, konsumsi energi terus meningkat. Berdasarkan proyeksi, kebutuhan gas bumi Indonesia misalnya akan meningkat sekitar 400\%-500\% di tahun 2025 dibanding kebutuhan gas bumi pada tahun 2011, dengan asumsi penerapan kebijakan migrasi BBM ke BBG pada sektor transportasi dan sektor pembangkit listrik. ${ }^{7}$ Peningkatan penggunaan migas tersebut seiring dengan pertumbuhan ekonomi dan peningkatan jumlah penduduk. Sebagai konsekuensinya, kekurangan migas kemudian dipenuhi dengan impor yang jumlahnya hingga kini selalu meningkat dari tahun ke tahun. ${ }^{8}$

Menurunnya produksi migas Indonesia tersebut harus segera dicari jalan keluarnya. Selain membuat kebijakan mix energy, pemerintah juga berupaya untuk kembali meningkatkan produksi dan cadangan migas. Kepala Humas SKK Migas Rudianto Rimbono mengatakan hingga 31 Oktober 2014, realisasi program eksplorasi baru mencapai 51 persen. Pengeboran sumur pengembangan hanya 73 persen dan Kegiatan lainnya adalah kerja ulang 76 persen dan perawatan sumur 74 persen.Sementara untuk kegiatan survei seismik, geologi, dan geofisika, hanya terealisasi 63 persen. Industri hulu migas baru bisa menyelesaikan pengeboran 67 sumur, dari 132 sumur yang direncanakan. Dari jumlah tersebut, 52 sumur merupakan sumur migas konvensional dan sisanya 15 adalah sumur nonkonvensional. Penurunan produksi minyak Indonesia disebabkan minimnya kegiatan eksplorasi Migas. ${ }^{9}$ Padahal potensi cadangan

5 Eka, "Menkeu: Indonesia Net Importir Minyak Sejak 2003," Aktual.com, 2014, https://aktual.com/?p=106018.

${ }^{6}$ SKK Migas, "Menuju 1 Juta BOPD \& 12 BSCFD di 2030 melalui Kegiatan Masif, Agresif dan Efisien," 2020.

7 Bertha Maya Sopha, "Kebutuhan-Dan-Ketersediaan-Gas-Alam-Indonesia.Pdf," Pusat Studi Energi, n.d., https://pse.ugm.ac.id/wp/wp-content/uploads/Kebutuhan-dan-ketersediaan-gas-alamIndonesia.pdf.

8 Mohamad Nasir, "Potret Kinerja Migas Indonesia Kementrian Keuangan," n.d., https://www.kemenkeu.go.id/sites/default/files/potret kinerja migas indonesia.pdf.

9 Safrezi Fitra, "Pelaksanaan Kegiatan Hulu Migas Masih di Bawah Target," Katadata.co.id, 2014, https://katadata.co.id/safrezifitra/energi/5e9a5707ca795/pelaksanaan-kegiatan-hulu-migas-masih-dibawah-target\#sthash.BSDqMvSv.dpuf. 
migas yang terkandung di bumi Indonesia diperkirakan masih cukup besar. ${ }^{10}$ Menteri Energi dan Sumber Daya Mineral (ESDM) menyampaikan bahwa per tanggal 19 Januari 2021, cadangan minyak Indonesia masih tersedia untuk 9,5 tahun dan cadangan gas 19,9 tahun ke depan. Perkiraan angka cadangan minyak dan gas bumi tersebut diberi asumsi ketika tidak ada penemuan baru dan tingkat produksi minyak saat ini tetap sebanyak 700 ribu barel oil per day (bopd) dan gas 6 billion standard cubic feet per day (bscfd). ${ }^{11}$ Banyaknya eksplorasi migas dipercaya dapat menstimulus peningkatan lifting migas.

Sayangnya, kegiatan eksplorasi migas beberapa tahun terakhir relatif minim, bahkan Indonesia terancam defisit gas di tahun 2023. ${ }^{12}$ Minimnya kegiatan eksplorasi salah satunya disebabkan oleh proses perizinan yang berbelit di sektor eksplorasi Migas. Berbelit dan panjangnya proses perizinan yang harus dilalui oleh investor sebelum melakukan usaha migas di Indonesia dapat dilihat dari banyaknya jumlah izin yang harus mereka miliki dan lamanya waktu yang dibutuhkan untuk memperoleh masing-masing izin. Untuk usaha hulu dan hilir migas misalnya diperlukan sekitar 200 izin. Izin-izin tersebut rumit dan membutuhkan waktu yang lama dalam pengurusannya, serta melibatkan banyak instansi. ${ }^{13}$

Untuk itu pemerintah kemudian mengeluarkan Peraturan Pemerintah Nomor 24 Tahun 2018 (PP 24/2018) tentang Pelayanan Perizinan Berusaha Terintegrasi Secara Elektronik (disebut juga dengan Online Single Submission / OSS). PP 24/2018 ini ditandatangani oleh Presiden Joko Widodo pada bulan Juni 2018 dengan harapan dapat menjadi solusi dari problematika kerumitan perizinan di Indonesia. Namun demikian, setelah lebih dari dua tahun diundangkan, kenyataan di lapangan menunjukkan bahwa penerapan PP ini masih menghadapai banyak kendala, ${ }^{14}$ termasuk kendala di bidang hukum. ${ }^{15}$ Hingga saat ini, meskipun sudah dikeluarkan PP 24/2018, para calon investor masih banyak yang mengeluhkan kerumitan serta lamanya proses agar bisa

10 Fahmi Radhy, "Rezim Perijinan Menghambat Produksi Migas," Kompasiana.com, 2014, https://www.kompasiana.com/fahmy_radhi/54f9329aa33311ef048b488c/rezim-perijinan-menghambatproduksi-migas.

11 Agung Pribadi, "Menteri ESDM: Cadangan Minyak Indonesia Tersedia untuk 9,5 Tahun dan Cadangan Gas 19,9 Tahun,” Kementerian Energi dan Sumber Daya Mineral, 2021.

12 Admin, "Eksplorasi Migas Minim, Indonesia Terancam Defisit Gas 2023," Migas Hulu Jabar ONWJ, 2020, https://www.migashulujabaronwj.co.id/eksplorasi-migas-minim-indonesia-terancamdefisit-gas-2023.

13 Radhy, "Rezim Perijinan Menghambat Produksi Migas."

${ }^{14}$ Lorenzo Anugrah Mahardika, "Implementasi Sistem OSS Masih Hadapi Sejumlah Kendala | Ekonomi," Bisnis.com, 2019, https://ekonomi.bisnis.com/read/20190911/9/1147045/implementasi-sistemoss-masih-hadapi-sejumlah-kendala.

15 Inosentius Samsul, "Kontroversi PP No 24 Tahun 2018," Mediaindonesia.com, 2018, https://mediaindonesia.com/read/detail/175843-kontroversi-pp-no-24-tahun-2018. 
melakukan kegiatan usahanya di Indonesia (termasuk kegiatan usaha hulu migas). Untuk itulah, menarik untuk dianalisis permasalahan-permasalahan di bidang perizinan migas setelah diberlakukannya PP 24/2018, termasuk setelah berlakunya UU Cipta Kerja. Berdasarkan pada permasalahan di bidang perizinan migas, penulis akan melakukan evaluasi terhadap penerapannya. Hasil evaluasi mengenai penerapan peraturan tentang perizinan berusaha di sektor hulu migas akan penulis sertai dengan rekomendasi yang dapat membantu berbagai stakeholder untuk menentukan langkah yang sepatutnya ditempuh kedepannya.

Penelitian Sasono dkk (2021), "Forestry Borrow To Use Permit In Upstream Oil And Gas Activity: Ecology Governance, Development Administration, And Administration Law Perspective" menganalisis tentang ketidakcocokan mekanisme perizinan hak pinjam pakai hutan untuk kegiatan hulu migas. ${ }^{16}$ Salah satu hal yang disoroti pada tulisan tersebut adalah mengenai prosedur permohonan hak pinjam pakai migas oleh Kontraktor Kerja Sama (KKS) untuk dapat melakukan kegiatan hulu migas di hutan, padahal hakikatnya kegiatan hulu migas bukan an sich milik KKS, melainkan kegiatan negara yang seharus didukung dengan penetapan. ${ }^{17}$ Tulisan tersebut memiliki kesamaan dengan tulisan ini karena membahas hakikat izin dan penetapan pada hulu migas. Namun, penelitian ini berbeda karena melihat perizinan hulu migas secara umum bukan hanya hak pinjam pakai hutan. Hasil dari penulisan ini memperkuat temuan pada penelitian Sasono ini menyatakan bahwa harus ada kekhususan mekanisme perijinan di hulu migas untuk mendukung peningkatan investasi hulu migas.

Penelitian mengenai peranan negara dalam kegiatan hulu migas juga dilakukan Redi (2016) dalam artikelnya yang berjudul "Dinamika Konsepsi Penguasaan Negara Atas Sumber Daya Alam”. Dalam tulisan tersebut, Redi menggambarkan dinamika interpretasi terkait hak menguasai negara yang diatur oleh Pasal 33 UUD 1945. ${ }^{18}$ Tulisan tersebut menjadi inspirasi dalam penelitian ini khususnya terkait peran negara yang seharusnya dalam kegiatan hulu migas. ${ }^{19}$ Tulisan ini berbeda dengan tulisan Redi karena bersifat lebih teknis dan konkrit. Hasil dari penelitian ini akan memperkaya tulisan Redi dengan praktik dilapangan mengingat tulisan Redi tersebut bersifat konseptual.

16 Didik Sasono Setyadi, Deti Mulyati, dan Azeem Marhendra Amedi, "Forestry Borrow to Use Permit in Upstream Oil and Gas Activity: Ecology Governance, Development Administration, and Administration Law Perspective," Yuridika 36, no. 1 (1 Januari 2021): 39, https://doi.org/10.20473/ydk.v36i1.21420.

17 Setyadi, Mulyati, dan Amedi.

18 Ahmad Redi, "Dinamika Konsepsi Penguasaan Negara Atas Sumber Daya Alam,” Jurnal Konstitusi 12, no. 2 (20 Mei 2016): 401, https://doi.org/10.31078/jk12210.

19 Redi. 
Penelitian lain yang menyangkut perizinan di hulu migas dilakukan Sujatmoko dkk (2020) yang berjudul "The simplification of Upstream Oil and Gas Business license in Indonesia." Dalam tulisan tersebut disebutkan bahwa perizinan migas sangat banyak, tumbang tindih dan memerlukan waktu yang lama, sehingga pemerintah perlu untuk menyederhanakan baik dari segi jumlah maupun prosedur perizinan migas. ${ }^{20}$ Penelitian tersebut serupa dengan penelitian ini karena membicarakan izin di hulu migas. Penelitian ini berbeda dari penelitian Sujatmoko, baik dari segi waktu maupun cakupannya. Penelitian ini menganalisis perizinan hulu migas setelah pemberlakuan PP 24/2018 juga UU Cipta Kerja. Dari segi cakupan, penelitian Sujatmoko bersifat lebih general yaitu Sujatmoko, yang berjudul "The simplification of Upstream Oil and Gas Business license in Indonesia" melengkapi penelitian sebelumnya karena mendeskripsikan secara lebih detail kesulitan yang ditemui pada pengurusan perizinan hulu migas.

Penelitian lain yang juga mengunspirasi penelitian ini adalah penelitian yang dilakukan Suryajaya dkk (2014) yang berjudul "SKK Migas Sistem Operasi Terpadu-Performance Evaluation for Secure Data Exchange for Oil and Gas Contractors". ${ }^{21}$ Tulisan tersebut menganalisa peluang-peluang peningkatan pada layanan Sistem Operasi Terpadu SKK Migas sampai tahun 2014. Penelitian ini berbeda dengan penelitian Bobby Suryajaya dkk karena hanya sebagian kecil tulisan ini yang menganalisis tentang ODSP (yang cikal bakalnya dari Sistem Operasi Terpadu) dan jangka waktu penelitian ini juga jauh setelah 2014. Penelitian ini bertujuan untuk mengevaluasi kesesuaian sistem perizinan berusaha terintegrasi secara elektronik terhadap sektor hulu minyak dan gas bumi (migas), baik sebelum maupun setelah berlakunya UndangUndang Cipta Kerja.

\section{B. Permasalahan}

Sebagaimana telah dipaparkan sebelumnya bahwa masih banyak permasalahan yang terjadi dalam penerapan PP 24/2018 sehingga tujuan dari dikeluarkannya PP tersebut belum tercapai, maka tulisan ini akan:

1. Menggambarkan karakteristik usaha hulu Migas;

2. Melakukan inventarisasi dan mapping perizinan di sektor hulu migas setelah diberlakukannya PP 24/2018;

\footnotetext{
20 Emanuel Sujatmoko et al., "The simplification of Upstream Oil and Gas Business license in Indonesia," Research, Society and Development 9, no. 2 (1 Januari 2020): e16921950, https://doi.org/10.33448/rsd-v9i2.1950.

21 Bobby Suryajaya, Charles Lim, dan Budi Ibrahim, "SKK Migas Sistem Operasi TerpaduPerformance Evaluation for Secure Data Exchange for Oil and Gas Contractors," Advanced Science Letters 20, no. 1 (1 Januari 2014): 129-33, https://doi.org/10.1166/asl.2014.5248.
} 
3. Melakukan evaluasi dan analisis kesesuaian PP 24/2018 dengan kebutuhan kegiatan hulu migas;

4. Memberikan rekomendasi untuk memperbaiki perizinan migas kedepan termasuk setelah dikeluarkannya UU Cipta Kerja dan PP Perizinan Berbasis Resiko.

\section{Metode Penelitian}

Metode penelitian yang digunakan dalam tulisan ini adalah metode penelitian hukum normatif. Penelitian hukum normatif disebut juga penelitian yuridis normatif yang artinya penelitian hukum dilakukan dengan meneliti bahan pustaka atau sekunder. ${ }^{22}$ Oleh karena itu dalam penelitian ini data utama yang digunakan adalah data sekunder, seperti buku, jurnal, peraturan perundangundangan, dan berbagai artikel terkait. Teknik yang dilakukan untuk mengumpulkan data ialah melalui studi pustaka. Selain melalui studi pustaka, keikutsertaan penulis dalam berbagai FGD yang diselenggarakan SKK Migas dan Kementerian ESDM terkait upaya penyederhaan perizinan migas sangat membantu pengayaan materi penelitian ini. Setelah terkumpul, terhadap data sekunder yang diperoleh kemudian dilakukan analisis data secara kualitatif. Pendekatan yang digunakan pada penelitian ini adalah pendekatan konseptual dan pendekatan peraturan perundang-undangan.

\section{HASIL DAN PEMBAHASAN}

\section{A. Karakteristik Usaha Hulu Migas}

Sebelum membahas tentang sistem perizinan, tulisan ini akan terlebih dahulu menginventarisir karakteristik kegiatan usaha hulu minyak dan gas bumi. Penjelasan mengenai karakteristik kegiatan usaha hulu migas ini akan sangat bermanfaat dalam analisis kesesuaian sitem perizinan menurut PP 24/2018 dengan karakteristik kegiatan hulu migas.

Secara normatif, kegaiatan usaha hulu minyak dan gas bumi di Indonesia saat ini diatur oleh Undang-undang Nomor 22 Tahun 2001 Tentang Minyak dan Gas Bumi (UU 22/2001) serta Putusan Mahkamah Konsitusi Nomor 002/ PUU - I/2003 dan Putusan Mahkamah Konstitusi Nomor 36 /PUU - X/2012. ${ }^{23}$ Dalam Konsideran (Menimbang huruf b) Undang-undang Nomor 22 Tahun 2001 disebutkan bahwa migas merupakan merupakan sumber daya alam

22 Soerjono Soekanto, Penelitian Hukum Normatif: Suatu Tinjauan Singkat (Jakarta: Raja Grafindo Persada, 2014).

${ }^{23}$ Mailinda Eka Yuniza et al., "Natural gas aggregation and the opportunity for synchronization under Indonesian law," The Journal of World Energy Law \& Business 9, no. 5 (6 Oktober 2016): 388-409, https://doi.org/10.1093/jwelb/jww021. 
strategis, komoditas vital yang menguasai hajat hidup orang banyak ${ }^{24}$ dan mempunyai peranan penting dalam perekonomian nasional. Oleh karena itu, maka migas dikuasai oleh negara dan pengelolaannya harus dapat secara maksimal memberikan kemakmuran dan kesejahteraan rakyat. Lebih lanjut UU 22/2001 mengatur bahwa penguasaan oleh negara diselenggarakan oleh pemerintah sebagai pemegang kuasa pertambangan dan pemerintah kemudian membentuk Badan Pelaksana. ${ }^{25}$

Pada perkembangannya, ketentuan tentang Badan Pelaksana kemudian di judicial review ke Mahkamah Konstitusi (MK). Putusan MK berkaitan dengan Badan Pelaksana Minyak dan Gas Bumi ialah Putusan Nomor 36/PUU-X/2012 yang dalam amarnya menyatakan bahwa "seluruh hal yang terkait dengan Badan Pelaksana bertentangan dengan Undang-Undang Dasar Negara Republik Indonesia Tahun 1945 dan tidak mempunyai kekuatan hukum mengikat." Selanjutnya, fungsi dan tugas Badan Pelaksana Minyak dan Gas Bumi dilaksanakan oleh Pemerintah. Dikarenakan adanya pengujian materiil terhadap Undang-Undang No. 22 Tahun 2001 ini maka sejak tahun 2012 Badan Pelaksana untuk sementara waktu digantikan oleh Satuan Kerja Khusus Pelaksana Kegiatan Usaha Hulu Minyak dan Gas Bumi (SKK Migas) ${ }^{26}$ berdasarkan Peraturan Presiden Nomor 9 Tahun 2013 tentang Penyelenggaraan Pengelolaan Kegiatan Usaha Hulu Minyak dan Gas Bumi. ${ }^{27}$ Perpres tersebut kemudian diubah dengan Peraturan Presiden Nomor 36 Tahun 2018 tentang Perubahan atas Peraturan Presiden Nomor 9 Tahun 2013 tentang Penyelenggaraan Pengelolaan Kegiatan Usaha Hulu Minyak dan Gas Bumi. ${ }^{28}$

Selain tentang Badan Pelaksana, UU 22/2001 juga mengatur tentang kontrak kerjasama. ${ }^{29}$ Pasal 6 ayat (1) UU 22/2001 menegaskan bahwa kegiatan

\footnotetext{
${ }^{24}$ Mailinda Eka Yuniza, Marsudi Triatmodjo, dan Rizkia Evania, "Gas governance in Indonesia," The Journal of World Energy Law \& Business 9, no. 2 (April 2016): 124-34, https://doi.org/10.1093/jwelb/jww004.

25 “Pasal 4 ayat (1), (2) dan (3) Undang-Undang Nomor 22 Tahun 2001 Tentang Minyak dan gas Bumi” (2001).

${ }^{26}$ M. Ilham F Putuhena, "Politik Hukum Pengelolaan Hulu Migas Pasca Putusan Mahkamah Konstitusi," Jurnal Rechts Vinding: Media Pembinaan Hukum Nasional 4, no. 2 (31 Agustus 2015): 237, https://doi.org/10.33331/rechtsvinding.v4i2.22.

27 "Peraturan Presiden Nomor 9 tahun 2013 Tentang Penyelenggaran Pengelolaan Kegiatan Usaha Hulu Minyak dan Gas Bumi” (2013); Jamie Seth Davidson, “The Demise of Indonesia's Upstream Oil and Gas Regulatory Agency: An Alternative Perspective," Contemporary Southeast Asia 37, no. 1 (30 April 2015): 109-33, https://doi.org/10.1355/cs37-1e.

28 "Peraturan Presiden Nomor 36 tahun 2018 Tentang Perubahan Atas Peraturan Presiden Nomor 9 Tahun 2013 Tentang Penyelenggaraan Pengelolaan Kegiatan Usaha Hulu Minyak dan Gas Bumi” (2018).

${ }^{29}$ Faizal Kurniawan, "Bentuk Perlindungan Hukum Terhadap Kekayaan Minyak dan Gas Bumi Sebagai Aset Negara Melalui Instrumen Kontrak," Perspektif 18, no. 2 (27 Mei 2013): 74, https://doi.org/10.30742/perspektif.v18i2.116.
} 
usaha hulu migas dilaksanakan dan dikendalikan melalui kontrak kerjasama. Kontrak kerjasama paling sedikit memuat persyaratan: ${ }^{30}$

a. kepemilikan sumber daya alam tetap di tangan pemerintah sampai pada titik penyerahan;

b. pengendalian manajemen operasi berada pada Badan Pelaksana;

c. modal dan risiko seluruhnya ditanggung Badan Usaha atau Bentuk Usaha Tetap.

Untuk melaksanakan UU 22/2001, pemerintah kemudian menerbitkan Peraturan Pemerintah Nomor 35 Tahun 2004 (PP 35/2004) Tentang Kegiatan Usaha Hulu Minyak dan Gas Bumi. ${ }^{31}$ PP 35/2004 terdiri dari 14 bab dan 105 pasal. PP ini secara lebih detail telah menjelaskan bagaimana seharusnya kegiatan industri hulu migas dijalankan. PP 35/2004 misalnya mengatur tentang kontraktor, kontrak kerjasama, dan wilayah kerja.

Pada Pasal 1 angka 6 PP 35/2004 disebutkan bahwa kontraktor adalah "Badan Usaha atau Bentuk Usaha Tetap yang diberikan wewenang untuk melaksanakan eksplorasi dan eksploitasi pada suatu wilayah kerja berdasarkan kontrak kerja sama dengan Badan Pelaksana." Ketentuan tentang kontraktor sebagai badan yang memiliki wewenang untuk melakukan ekplorasi dan eksploitasi migas tersebut kemudian diperjelas lagi di dalam Pasal 24. Dalam Pasal 24 ayat (1) PP 35/2004 diatur bahwa "Kegiatan Usaha Hulu dilaksanakan oleh Badan Usaha atau Bentuk Usaha Tetap berdasarkan Kontrak Kerja Sama dengan Badan Pelaksana”.

Mengenai kontraktor sebagai badan usaha atau bentuk usaha tetap definisinya merujuk kepada Ketentuan Pasal 1 angka 17 dan angka 18 UU 22/2001. Pada Pasal 1 angka 17 UU 22/2001 diatur bahwa Badan Usaha (BU) adalah "perusahaan berbentuk badan hukum yang menjalankan jenis usaha bersifat tetap, terus-menerus dan didirikan sesuai dengan peraturan perundangundangan yang berlaku serta bekerja dan berkedudukan dalam wilayah Negara Kesatuan Republik Indonesia”. Sedangkan, Bentuk Usaha Tetap (BUT) diatur dalam Pasal 1 angka 18 UU 22/2001 yang berbunyi:

"Bentuk Usaha Tetap adalah badan usaha yang didirikan dan berbadan hukum di luar wilayah Negara Kesatuan Republik Indonesia yang melakukan kegiatan di wilayah Negara Kesatuan Republik Indonesia dan wajib mematuhi peraturan perundang-undangan yang berlaku di Republik Indonesia”.

\footnotetext{
30 Pasal 6 ayat (2) Undang-Undang Nomor 22 Tahun 2001 Tentang Minyak dan gas Bumi.

31 "Peraturan Pemerintah Nomor 35 tahun 2004 Tentang Kegiatan Usaha Hulu Minyak dan Gas Bumi” (2004)
} 
Terhadap setiap BU dan BUT hanya dapat diberikan satu wilayah kerja. ${ }^{32}$ Dalam hal badan usaha atau bentuk usaha tetap mengusahakan lebih dari satu wilayah kerja, maka harus dibentuk badan hukum yang terpisah untuk setiap wilayah kerja. ${ }^{33}$ Terkait dengan ketentuan tersebut, jika di Indonesia ada BU atau BUT yang mengusahakan beberapa wilayah kerja di Indonesia, maka badan hukumnya harus berbeda untuk wilayah kerja yang satu dengan wilayah kerja yang lainnya. Contohnya Medco, maka Medco yang berwilayah kerja di Natuna, dengan Medco yang berwilayah kerja di Sumatera Selatan serta yang berwilayah kerja di Madura, adalah badan hukum yang terpisah-pisah (tidak bisa diwakili oleh satu manajemen atau pengurus saja).

Selain mengatur tentang kontraktor, hal penting lainnya yang diatur PP 35/ 2004 adalah mengenai kontrak Kerjasama dan asset kegiatan hulu migas. Pasal 24 ayat (2) PP 35/2004 menjelaskan tentang persyaratan kontrak kerjasama yang paling sedikit harus memuat:

a. kepemilikan sumber daya Minyak dan Gas Bumi tetap ditangan pemerintah sampai pada titik penyerahan;

b. pengendalian manajemen atas operasi yang dilaksanakan oleh kontraktor berada pada Badan Pelaksana;

c. modal dan risiko seluruhnya ditanggung oleh Kontraktor.

Mengenai aset Kegiatan Usaha Hulu Minyak dan Gas Bumi diatur secara jelas dalam Pasal 78 PP No. 35 Tahun 2004 yang bunyinya: "Seluruh barang dan peralatan yang secara langsung digunakan dalam kegiatan usaha hulu yang dibeli kontraktor menjadi milik/kekayaan negara yang pembinaannya dilakukan oleh pemerintah dan dikelola oleh Badan Pelaksana".

Berdasarkan ketentuan-ketentuan diatas sangat jelas bahwa kegiatan usaha hulu minyak dan gas bumi adalah kegiatan pemerintah yang diwakili oleh Badan Pelaksana (dahulu BPMIGAS, sekarang SKK Migas) karena:

1. Kepemilikan Sumber Daya Alam (Migas) ada di tangan Pemerintah sampai di titik penyerahan;

2. Manajemen Operasi Kegiatan Usaha Hulu Migas ada pada SKK Migas

3. Aset yang digunakan langsung untuk kegiatan usaha hulu migas yang dibeli oleh BU / BUT (kontraktor) adalah kekayaan negara yang dikelola oleh Badan Pelaksana (SKK Migas);

4. BU / BUT (Kontraktor) hanya operator yang bertanggung jawab menyediakan modal dan menanggung risiko;

Dengan demikian peran pemerintah dalam kegiatan usaha hulu minyak dan gas bumi yang diwakili oleh SKK Migas sangatlah dominan, sebagai "pemilik"

\footnotetext{
32 Pasal 13 Undang-Undang Nomor 22 Tahun 2001 Tentang Minyak dan gas Bumi.

33 Pasal 13 ayat (2) Undang-Undang Nomor 22 Tahun 2001 Tentang Minyak dan gas Bumi.
} 
sumber daya migas, sekaligus pemegang manajemen operasi, serta sebagai pemilik semua asset usaha hulu.

Mengenai hal ini Didik S Setyadi menyebutkan "Posisi pemerintah yang sangat dominan tidak lepas dari amanat konstitusi yang "mengharuskan" pemerintah (untuk dan atas nama negara) berkedudukan seperti itu". ${ }^{34}$ Dengan kata lain maka bila pemerintah melaksanakan kegiatan usaha hulu minyak dan gas bumi dapat dikatakan bahwa pemerintah sudah melaksanakan "kewajiban"/“tugas" konstitusional sebagai wujud pelaksanaan hak menguasai negara atas kekayaan alam minyak dan gas bumi untuk sebesar-besarnya kemakmuran rakyat. Dari uraian di atas, pada bukunya yang lain Didik Sasono Setyadi menyatakan: ${ }^{35}$

"Secara lebih luas dapat disimpulkan, ketentuan tersebut memberikan pengertian bahwa setiap barel minyak dan atau setiap kali kubik gas yang diproduksi, beserta asset-aset penunjang produksi yang terpasang adalah milik negara. Oleh karena itu perlu dikendalikan biaya investasi dan produksinya oleh badan milik pemerintah yang disebut SKK Migas agar dapat menghasilkan penerimaan negara yang maksimal. Mengapa demikian? karena biaya investasi dan produksi tersebut harus dibayar kembali dalam bentuk hasil produksi (minyak dan atau gas bumi) oleh pemerintah kepada Badan Usaha atau Bentuk Usaha Tetap yang bersangkutan sebelum dilakukan bagi hasil untuk Pemerintah dan untuk Badan Usaha atau Bentuk Usaha Tetap. Pengembalian biaya investasi dan produksi inilah yang lazim disebut Cost recovery".

Pernyataan Didik S Setyadi ini mengandung pengertian bahwa peran pemerintah sebagai pemilik sumber daya migas dan pemegang manajemen operasi harus dioptimalkan untuk mengendalikan agar investasi dan biaya operasi untuk eksplorasi dan eksploitasi migas terkelola dengan baik. Sekalipun yang menyediakan modal adalah kontraktor namun kontraktor tidak bisa seenaknya / serta merta membelanjakan uang untuk investasi dan biaya operasinya. Mereka harus mendapatkan persetujuan lebih dahulu dari pemerintah (dalam hal ini SKK Migas) karena modal dan biaya operasi ini nantinya akan dikembalikan dari hasil produksi dalam bentuk Cost recovery (CR). Bila CR besar maka hasil minyak yang dibagi antara negara dengan kontraktor makin sedikit, sehingga ujungnya akan mengurangi manfaat bagi rakyat dan negara.

34 Didik S Setyadi, Politik Hukum Dinamika Penerapan Hak Menguasai Negara Atas Sumber Daya Alam Minyak Gas Bumi (Surabaya: Sahabat Mandiri, 2017).

35 Setyadi, Mulyati, dan Amedi, "Forestry Borrow to Use Permit in Upstream Oil and Gas Activity: Ecology Governance, Development Administration, and Administration Law Perspective." 
CR ini adalah keniscayaan dalam semua kegiatan usaha, termasuk dalam kegiatan usaha hulu migas, oleh karena itu Benny Lubiantara menyatakan: ${ }^{36}$

"Di dalam kontrak migas antara pemerintah dengan perusahaan migas, pada dasarnya apapun sistem kontrak migas yang digunakan, akan selalu ada yang namanya mekanisme cost recovery. Mekanisme ini ini sebenarnya tidak hanya terdapat pada sistem kontrak kerja sama dalam industry hulu migas (Production Sharig Contract/PSC), juga pada sistem konsesi (royalty / tax), namun memang istilah yang digunakan bukan cost recovery, tetapi cost deductions".

Lebih lanjut, Benny Lubiantara mempertanyakan pendapat pengamat yang mengusulkan agar PSC tidak lagi digunakan hanya karena adanya mekanisme Cost recovery mengingat bahwa pengawasan pemerintah justru lebih ketat dibanding dengan sistem konsesi. ${ }^{37}$ Untuk mengetahui mengapa kegiatan usaha hulu Migas merupakan kegiatan pemerintah dapat dilihat dari Prinsip-prinsip PSC yang dikenalkan oleh Ibnu Sutowo pada awal-awal hendak diberlakukannya PSC pada tahun 1966 adalah sebagai berikut: ${ }^{38}$

1. Kendali manajemen dipegang Perusahaan Negara

2. Kontrak didasarkan pada pembagian produksi

3. Kontraktor menanggung risiko pra-produksi. Bila minyak ditemukan, penggantian biaya (cost recovery) dibatasi maksimum $40 \%$ per tahun dari minyak yang dihasilkan.

4. Sisa minyak setelah dikurangi cost recovery dibagi dengan komposisi 65\% untuk Perusahaan Negara can 35\% untuk Kontraktor.

5. Pertamina membayar pajak pendapatan kontraktor pada pemerintah.

6. Kontraktor wajib mempekerjakan tenaga kerja Indonesia. Setelah produksi ekonomis dimulai, kontraktor wajib mendidik dan melatih tenaga kerja Indonesia.

7. Kontraktor wajib memenuhi kebutuhan bahan bakar minyak dalam negeri maksimum $25 \%$ dari bagian yang dihasilkan.

Prinsip-prinsip yang ditawarkan oleh Ibnu Sutowo ini pernah ditolak oleh perusahaan-perusahaan besar migas asing yang ada di Indonesia, namun pada akhirnya tetap ada perusahaan-perusahaan minyak dan gas bumi yang mendukung dan menerima prinsip-prinsip itu, sehingga sistem PSC saat ini banyak diikuti oleh negara-negara lain tentunya dengan penyesuaianpenyesuaian tertentu. 2013)

${ }^{36}$ Benny Lubiantara, Ekonomi Migas Tinjauan Aspek Komersial Kontrak Migas (Jakarta: Grasindo,

37 Lubiantara, 173.

38 Salim HS, Hukum Pertambangan di Indonesia (Jakarta: Raja Grafindo Persada, 2006). 
Keberatan terhadap sistem PSC $^{39}$ yang menggunakan mekanisme Cost recovery ini menjadikan pemerintah kemudian mengeluarkan kebijakan PSC Gross split. Berbeda dengan sistem Cost recovery dimana pemerintah kemudian mengganti biaya operasional yang dikeluarkan oleh kontraktor untuk eksplorasi dan eksploitasi migas, dalam sistem Gross split sudah ada ketentuan tentang bagi hasil yang jelas antara kontraktor dan pemerintah sejak awal dan semua biaya operasional ditanggung oleh kontraktor. ${ }^{40}$ Sayangnya, penerapan Gross split tidak berjalan lancar mengingat ketentuan-ketentuan yang dibuat pemerintah untuk sistem Gross split masih sangat premature. ${ }^{41}$ Lebih lanjut, sistem kontrak kerja sama Gross split yang mirip sistem Tax / Royalty (Konsesi), pada dasarnya juga mengenal cost recovery / cost deduction, hanya saja angkanya ditetapkan di depan. Rinto Pudyantoro menambahkan bahwa kesalahpahaman tentang Cost recovery berpangkal pada pemahaman yang salah yang mengira bahwa bisnis hulu migas adalah sepenuhnya bisnis kontraktor. ${ }^{42}$ Padahal sejatinya, sebagaimana telah dijelaskan diatas Kegiatan Usaha Hulu Migas adalah merupakan kegiatan pemerintah.

\section{B. Inventarisasi Dan Mapping Perizinan Di Sektor Hulu Migas Setelah Diperlakukannya PP 24/2018}

Seperti dijelaskan sebelumnya bahwa kegiatan usaha hulu minyak dan gas bumi adalah kegiatan pemerintah yang operasionalisasinya dilaksanakan oleh mitra pemerintah (dalam hal ini Kontraktor Kontrak Kerja Sama / KKKS). Untuk itu pada awal tahun 2020 SKK Migas membentuk One Door Service Policy (ODSP) Perizinan untuk mengukuhkan karakter tersebut.

ODSP merupakan layanan yang disediakan oleh SKK Migas untuk membantu proses perizinan KKKS yang dilaksanakan dalam satu pintu dan proses yang lebih cepat. SKK Migas dan KKKS bersama-sama melakukan penelitian atas kelengkapan untuk setiap persyaratan perizinan dari berbagai instansi yang ada saat ini dan SKK Migas kemudian akan membantu KKKS untuk dapat memenuhi dokumen yang menjadi persyaratan perizinan serta mendampingi pengurusan perizinan di di instansi terkait. ${ }^{43}$ Adapun proses

39 Maria R.U.D. Tambunan dan Ginda Togatorop, "Dualisme Ketentuan Cost Recovery Sebagai Dasar Pungutan Negara Pada Industri Hulu Migas," Veritas et Justitia 7, no. 1 (28 Juni 2021): 56-90, https://doi.org/10.25123/vej.v7i1.3740.

40 Mailinda Eka Yuniza, Aicha Grade Rebecca, dan Rahmah Candrika Ramadhaniati, "A Necessity or A Premature Move? The Shift of Indonesian Production Sharing Contract in the Oil and Gas Industry," International Journal of Energy Economics and Policy 10, no. 4 (15 Mei 2020): 251-57, https://doi.org/10.32479/ijeep.9024.

41 Yuniza, Rebecca, dan Ramadhaniati.

42 A Rinto Pudyantoro, A to Z Bisnis Hulu Migas (Jakarta: Petromindo, 2017).

43 Satuan Kerja Khusus Pelaksana Kegiatan Usaha Hulu Minyak dan Gas Bumi, "Kejar 1 Juta BOPD, SKK Migas Launching ODSP,” SKK Migas, 2020, http://www.skkmigas.go.id/berita/kejar-1-jutabopd-skk-migas-launching-odsp. 
inventarisasi kebutuhan perizinan yang dilakukan oleh OSDP ditunjukkan dalam gambar berikut:

Gambar 1. Proses Inventarisasi Kebutuhan Perizinan untuk Setiap Kegiatan Usaha Hulu Migas dan Strategi untuk Mendapatkannya

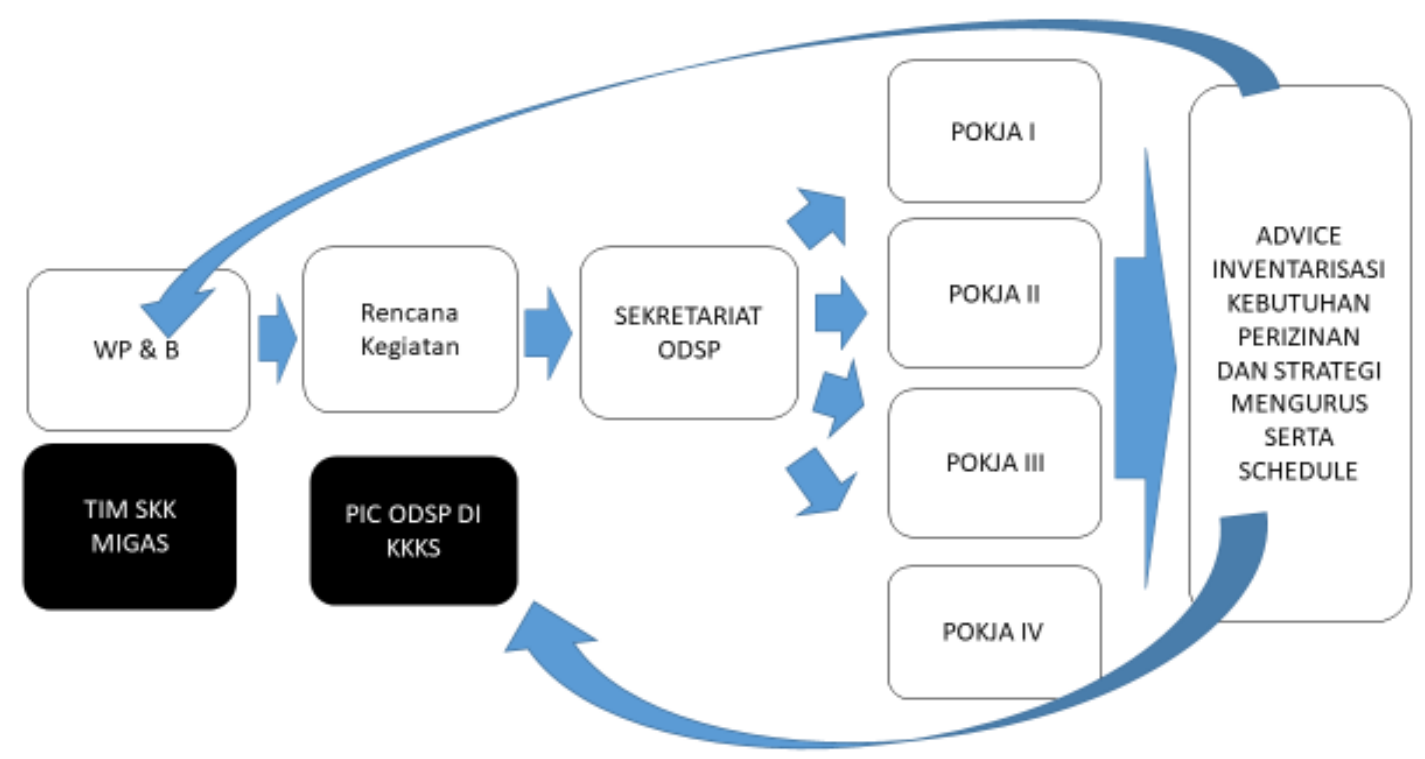

Berdasarkan Gambar 1, Nampak bahwa mekanisme kerja (Standard Operating Procedure) dari ODSP adalah sebagai berikut:

1. KKKS yang telah mendapatkan persetujuan WP\&B (Work Program \& Budget) mengajukan Rencana Kegiatan ke Sekretariat ODSP.

2. Sekretariat ODSP melanjutkan ke Kelompok-kelompok Kerja ODSP untuk menganalisa kebutuhan perizinan, persyaratan yang dibutuhkan serta strategi dan skedul untuk mendapatkannya yang dituangkan sebagai "Advis"

3. Setelah "Advis" keluar dari ODSP maka hal terebut diserahkan pada fungsi yang memonitor WP \& B di SKK Migas dan kepada PIC (Person in Charge) ODSP di masing-masing KKKS untuk ditindak lanjuti pengurusan izinnya, dibantu oleh ODSP

Berdasarkan Gambar 1 tampak bahwa ada 4 Pokja OSDP. Adapun tugas masingmasing kelompok kerja (Pokja 1 sampai dengan 4) adalah sebagai berikut: 
Gambar 2. Pembagian Kluster / Kelompok Kerja Berdasarkan Substansi Perizinan, beserta Leading Sektor Penerbit Izinnya

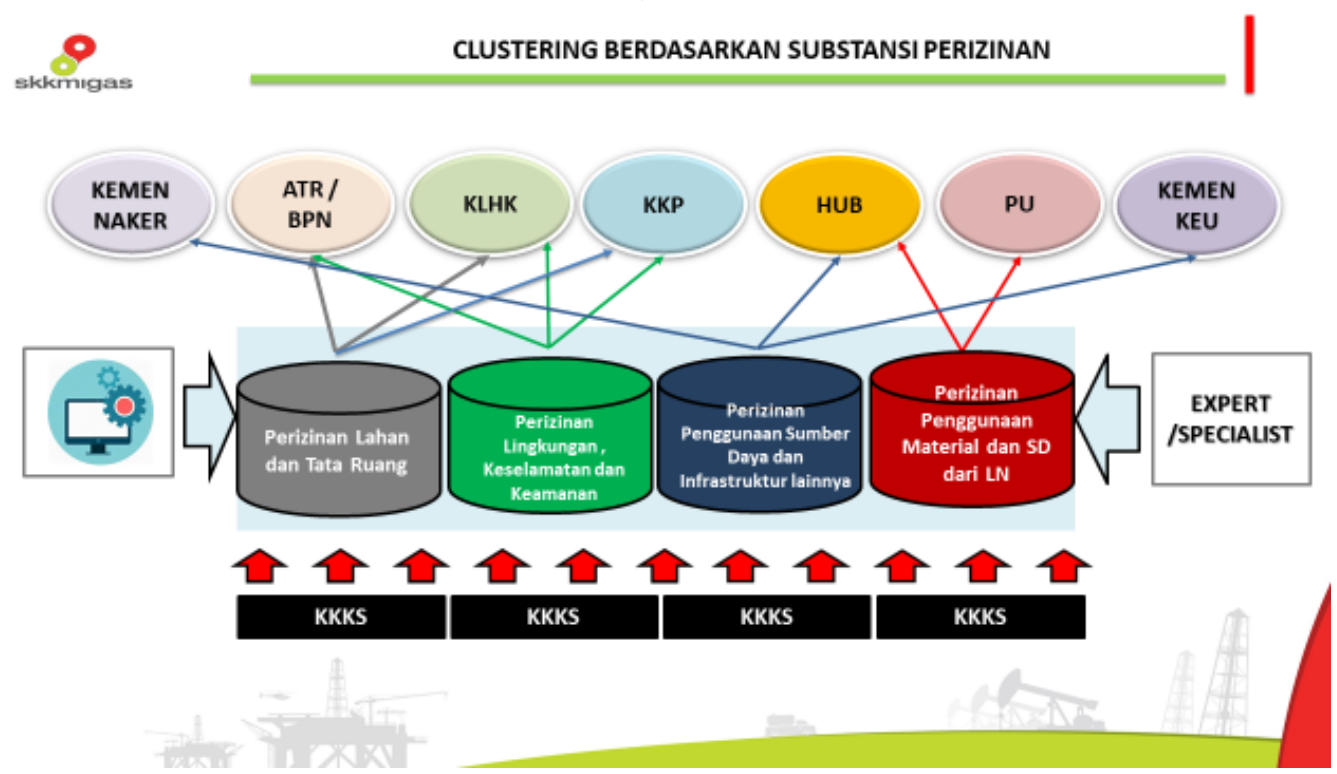

\section{Sumber: ODSP SKK Migas}

Perjalanan ODSP dimulai di bulan November 2019 yang diawali dengan perumusan konsep ODSP, FGD dan sosialisasi ke kalangan KKKS. ${ }^{44}$ Struktur ODSP terdiri atas 4 (empat) Kelompok Kerja (Pokja) yaitu :

1. Perizinan I yang mencakup lahan dan tata ruang. Pokja 1 ini berkordinasi dengan beberapa institusi seperti: Kementerian Agraria dan Tata Ruang/ Badan Pertanahan Nasional, Kementerian Lingkuhan Hidup dan Kehutanan. dan Kementerian Kelautan dan Perikanan.

2. Perizinan II yang mencakup lingkungan, keselamatan dan keamanan. Sama seperti Pokja 1, Pokja 2 juga berkoordinasi dengan Kementerian Agraria dan Tata Ruang/ Badan Pertanahan Nasional, Kementerian Lingkuhan Hidup dan Kehutanan. dan Kementerian Kelautan dan Perikanan.

3. Perizinan III yang mencakup Penggunaan Sumber Daya dan Infrastruktur lainnya. Pokja 3 ini berkoordinasi dengan Kementerian Tenaga Kerja, Kementerian Perhubungan, Kementerian Pekerjaan Umum, dan Kementerian Keuangan.

4. Perizinan IV yang mencakup Penggunaan Material dan Sumber daya dari Luar Negeri. Pokja 3 berkoordinasi dengan Kementerian Perhubungan dan Kementerian Keuangan.

${ }^{44}$ Bumi. 
Di bawah ini adalah data perizinan Kegiatan Usaha Hulu Migas yang dikonsultasikan dan diproses melalui ODSP SKK Migas pada tahun 2020 mulai bulan Januari sampai bulan Juli.

Gambar 3. Data Perizinan Kegiatan Usaha Hulu Migas yang Dikonsultasikan dan atau Diproses melalui ODSP SKK Migas dari Januari - Juli 2020

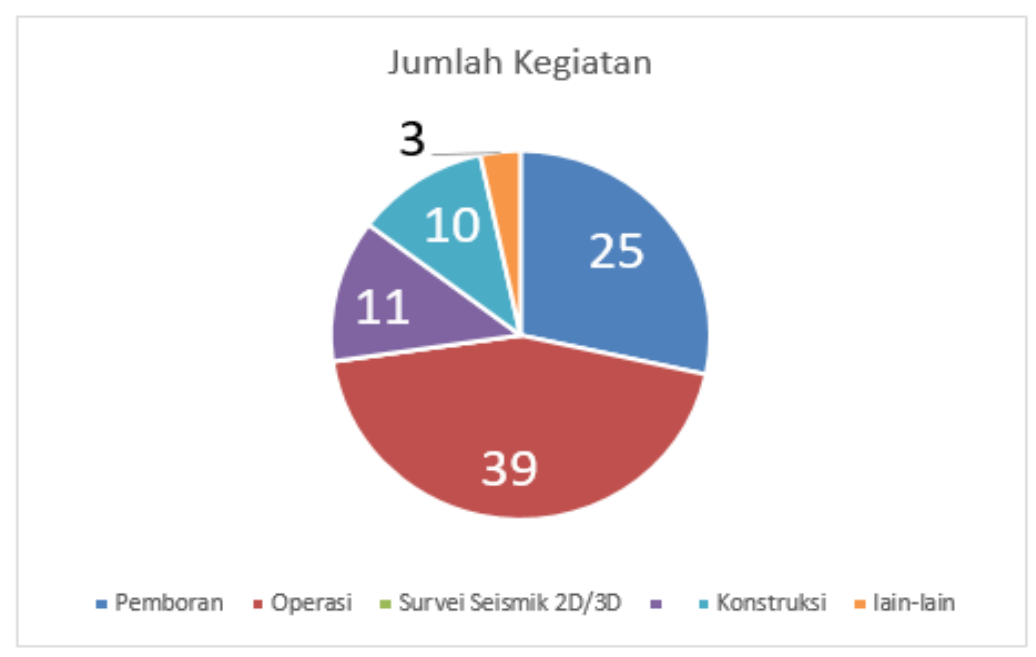

Berdasarkan gambar dibawah. Nampak bahwa OSDP sudah melakukan analisis terhadap 88 perizinan. Perizinan terkait dengan kegiatan operasi merupakan perizinan paling banyak dibutuhkan, disusul dengan kegiatan pengeboran, konstruksi dan seismik.

Gambar 4. Data Banyaknya Jenis Perizinan Yang Diurus oleh OSDP Berdasarkan

Kelompok Kerja / Kluster

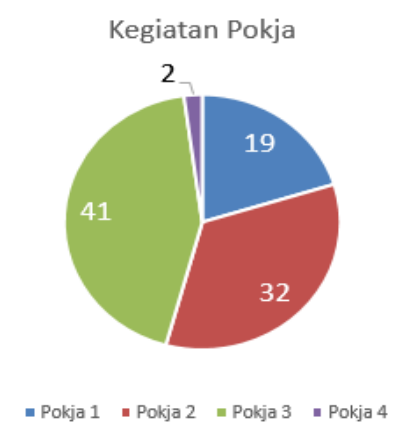

Dari data tersebut menunjukkan bahwa dari bulan Januari - Juli 2020 untuk kebutuhan kegiatan usaha hulu minyak dan gas bumi di Indonesia perizinan yang terbanyak adalah perizinan dalam Kelompok Kerja / Kluster 3: Perizinan Penggunaan Sumber Daya dan Infrastruktur Lainnya yang Leading Sectornya adalah Kementerian Perhubungan dan PUPR (utamanya). Terkait 
perizinan yang diurus oleh Pokja 3, kebetulan yang sudah menggunakan sistem OSS adalah Kementerian Perhubungan, sementara yang lainnya belum.

Berdasarkan uraian fakta dan problematika di atas, tulisan ini selanjutnya akan membahas hal-hal yang mendasar (filosofi dan prinsip-prinsip) dari administrasi pemerintahan, khususnya yang menyangkut konsep-konsep dasar tentang perizinan, subyek - obyek, ruang lingkup dan tujuan perizinan, untuk mengungkap apakah sistem OSS bisa efektif dijalankan untuk diterapkan dalam kegiatan usaha hulu minyak dan gas bumi. Bila belum, mengapa hal tersebut terjadi, serta bagaimanakah seharusnya sistem OSS ini disempurnakan agar lebih bermanfaat bagi kebutuhan kegiatan usaha hulu minyak dan gas bumi.

\section{Evaluasi Kesesuaian/Ketidaksesuain PP 24/2018 Dengan Kebutuhan Hulu Migas}

Bila kita lihat ketentuan-ketentuan dalam PP 24/2018 nampak bahwa PP ini dikeluarkan dalam konteks yang sangat umum dan berlaku bagi seluruh bidang usaha. Padahal, sebagaimana telah dijelaskan sebelumnya bahwa industri hulu migas merupakan bidang usaha khusus yang memiliki karakteristik yang berbeda dengan bidang usaha pada umumnya. Oleh karena itu, berdasarkan analisis terkait PP 24/2018 terdapat beberapa ketentuan dalam PP ini yang tidak sesuai dengan kebutuhan hulu migas, yaitu:

a. Terkait Ketentuan Pelaku Usaha dan pihak yang mengeluarkan OSS

Pada Pasal 1 angka 4 PP 24/2018 diatur bahwa perizinan berusaha adalah pendaftaran yang diberikan kepada pelaku usaha untuk memulai dan menjalankan usaha dan/atau kegiatan dan diberikan dalam bentuk persetujuan yang dituangkan dalam bentuk surat/keputusan atau pemenuhan persyaratan dan/atau komitmen. Berdasarkan definisi tersebut jelas bahwa yang dikenai kewajiban untuk memiliki izin berusaha adalah pelaku usaha. Pelaku usaha kemudian dijelaskan definisinya di dalam Pasal 1 angka 6 PP 24/2018 yang diartikan sebagai perseorangan atau non perseorangan yang melakukan usaha dan/atau kegiatan pada bidang tertentu. Pelaku usaha kemudian mengurus izin melalui OSS. Perizinan berusaha kemudian akan diterbitkan oleh lembaga OSS untuk dan atas nama menteri, pimpinan lembaga, gubernur, atau bupati/wali kota kepada pelaku Usaha melalui sistem elektronik yang terintegrasi. ${ }^{45}$

Jika dilihat ketentuan-ketentuan tersebut, maka nampaknya sudah jelas dan terang tentang siapa yang wajib memohon dan bagaimana perizinan berusaha diterbitkan. Namun, jika dihubungkan dengan pelaku usaha dalam kegiatan usaha hulu migas sebagaimana sudah dijelaskan sebelumnya, maka komplikasi akan muncul. Komplikasi muncul karena didalam kegiatan usaha

45 “Pasal 1 angka (5) Peraturan Pemerintah Republik Indonesia Nomor 24 Tahun 2018 tentang Pelayanan Perizinan Berusaha Terintegrasi Secara Elektronik” (2018). 
hulu migas, pelaku usahanya bukanlah kontraktor kontrak kerja (BU / BUT) saja, melainkan juga Kementerian ESDM selaku regulator dan penanggung jawab wilayah kerja, dan SKK Migas selaku pelaksana kegiatan yang memegang kendali manajemen operasi mewakili pemerintah sebagai pemilik kegiatan. Dengan kondisi seperti ini, bisa dibayangkan kesulitan yang muncul untuk menentukan siapakan yang berkewajiban untuk memohonkan izin berusaha sekaligus menjawab pertanyaan siapa yang akan mengeluarkan izin berusaha tersebut. Penting untuk dicatat bahwa sebagai perwakilan negara baik Kementerian ESDM maupun SKK migas berhak untuk disebut sebagai pelaku usaha, namun disisi lain juga berhak untuk mengeluarkan perizinan berusaha di bidang hulu migas. Tentu saja, concern tentang konflik kepentingan juga harus dijadikan pertimbangan.

b. Istilah Izin Usaha dalam Hulu Migas Tidak Dikenal Padahal Menjadi Prasyarat Izin Komersil.

Dalam Pasal 5 PP 24/2018 diatur bahwa izin berusaha terdiri dari izin usaha dan izin komersil atau operasional. Izin Usaha diartikan sebagai izin yang dikeluarkan setelah setelah pelaku usaha melakukan pendaftaran dan untuk memulai usaha dan/atau kegiatan sampai sebelum pelaksanaan komersial atau operasional dengan memenuhi persyaratan dan/atau komitmen. ${ }^{46}$ Sementara itu, izin komersil diartikan sebagai izin yang diterbitkan setelah setelah pelaku usaha mendapatkan izin usaha dan untuk melakukan kegiatan komersial atau operasional dengan memenuhi persyaratan dan/atau komitmen. ${ }^{47}$

Ketentuan mengenai izin izin usaha dan izin komersil tersebut tidak sesuai dengan kondisi riil kegiatan industri hulu migas. Kegiatan usaha hulu minyak dan gas bumi (eksplorasi dan eksploitasi) hanya boleh dilakukan oleh kontraktor setelah kontraktor menanda tangani PSC bersama SKK Migas, bukan melalui izin operasional maupun izin komersial. Sehingga izin komersial atau izin operasional dalam kegiatan eksplorasi dan eksploitasi minyak dan gas bumi tidak sesuai untuk kegiatan usaha hulu migas.

c. Ketentuan Izin Lokasi dalam PP 24/2018 tidak sesuai dengan sistem perizinan serupa di kegiatan hulu migas

Pengertian mengenai izin lokasi diatur dalam Pasal 1 angka 18 PP 24/2018 yaitu izin yang diberikan kepada pelaku usaha untuk memperoleh tanah yang diperlukan untuk usaha dan/atau kegiatannya dan berlaku pula sebagai izin pemindahan hak dan untuk menggunakan tanah tersebut untuk usaha dan/atau kegiatannya. Untuk wilayah perairan (daerah pesisir dan pulau-pulau kecil),

\footnotetext{
46 Pasal 1 angka (8) Peraturan Pemerintah Republik Indonesia Nomor 24 Tahun 2018 tentang Pelayanan Perizinan Berusaha Terintegrasi Secara Elektronik.

47 Pasal 1 angka (9) Peraturan Pemerintah Republik Indonesia Nomor 24 Tahun 2018 tentang Pelayanan Perizinan Berusaha Terintegrasi Secara Elektronik.
} 
dikenal adanya izin lokasi perairan. Dari ketentuan tersebut, dapat kita simpulkan bahwa PP 24/2018 sudah mengatur secara jelas bahwa untuk setiap kegiatan yang dilakukan pelaku usaha yang memerlukan tanah dalam kegiatannya, wajib untuk mendapatkan izin lokasi dan/atau izin lokasi perairan. Padahal, di bidang hulu migas sudah ada pengaturan spesifik tersendiri.

Kegiatan usaha hulu minyak dan gas bumi bisa dilakukan di daratan (Onshore) ataupun di perairan (Offshore). Untuk di daratan bila dilakukan di Kawasan Hutan maka izin yang diperlukan adalah menggunakan Izin Pinjam Pakai Kawasan Hutan sesuai ketentuan UU No. 41 Tahun 1999. Bila tanah yang diperlukan adalah tanah di luar kawasan hutan, maka perolehan tanah dilakukan dengan mekanisme penetapan lokasi sebagaimana diatur dalam UU No. 2 Tahun 2010 tentang Pengadaan Tanah Bagi Pembangungan Untuk Kepentingan Umum (bukan izin lokasi). Untuk kegiatan hulu migas di laut, perizinan yang selama ini diperlukan adalah penetapan lokasi perairan.

Berdasarkan hal tersebut, paling tidak ada 2 hal penting yang tidak sesuai, yaitu: 1. Jenis perizinan yang selama ini ada di hulu migas berbeda dengan ketentuan di PP 24/2018 dan 2. Istilah hukum yang dipakai di usaha hulu migas tidak semuanya merupakan izin, melainkan juga penetapan. Perbedaan tentang konsep izin dan penetapan juga menjadi penting untuk diperhatikan.

Merujuk pada teori-teori perizinan maka seharusnya untuk kegiatan usaha pemerintah bila memerlukan persetujuan dari lembaga pemerintah yang lain tidak digunakan instrumen keputusan berupa "izin" melainkan dengan persetujuan / perkenan dalam bentuk lain yang merupakan hasil koordinasi antara lembaga pemerintah yang berwenang bukan melalui proses "permohonan", tetapi melalui proses inisiasi dari leading sector mengundang sektor-sektor lain yang terkait. Bentuk yang lazim dikenal saat ini namanya "Penetapan".

d. Kesulitan Teknis jika kontraktor dianggap sebagai subyek pemohon izin usaha

Kesulitan untuk menentukan siapakan seharusnya pemohon izin usaha dalam konteks usaha hulu migas telah dijelaskan sebelumnya di poin a. Jika kita anggap bahwa subyek yang wajib memohon ijin usaha adalah kontraktor, karena adanya konflik kepentingan jika yang menjadi subyek adalah Kemeneterian ESDM ataupun SKK Migas, kesulitan selanjutnya muncul terkait dengan teknis persyaratan yang diatur di PP 24/2018. Pada Pasal 6 ayat (3) PP 24/2018 ditentukan bahwa salah satu pelaku usaha non perseorangan adalah perseroan terbatas (PT). Selanjutnya, Pasal 7 kemudian menjelaskan bahwa PT adalah perseroan terbatas sebagaimana dimaksud dalam undang-undang tentang perseroan terbatas, yang telah disahkan oleh kementerian yang menyelenggarakan urusan pemerintahan di bidang hukum. Permasalahannya, 
dalam kegiatan hulu migas, kontraktor adalah badan usaha dan bentuk usaha tetap yang harus berbeda untuk setiap wilayah kerja (harus badan hukum tersendiri). Oleh karena itu, tidak semua badan usaha atau bentuk usaha tetap di kegiatan usaha hulu migas dibentuk perseroan terbatan sendiri-sendiri namun hanya melalui suatu perjanjian berupa joint venture agreement.

Selanjutanya, dalam Pasal 21 ayat (2) PP 24/2018 sudah diatur cara mengakses laman OSS yang mengharuskan pelaku usaha non perorangan memasukkan nomor pengesahan akta pendirian atau nomor pendaftaran perseroan terbatas. Permasalahannya, jika kontraktor yang berbentuk BUT maka sudah pasti mereka tidak memiliki akte pendirian atau nomor pendaftaran perseroan terbatas karena tidak didirikan di Indonesia. Namun, bila kontraktornya berbentuk PT dan mengusahakan beberapa wilayah kerja di Indonesia, pertanyaannya apakah nomor pengesahan yang dimasukkan memang cukup nomor pengesahan satu PT saja untuk semua wilayah kerja, sementara menurut Undang-undang Migas setiap BU/BUT hanya diberikan satu wilayah kerja.

Permasalahan lainnya muncul terkait dengan ketentuan Pasal 22 ayat (2) yang mengatur tentang daftar isian yang harus diisi oleh pelaku usaha yang sudah dapat mengakses laman OSS. Dalam daftar isian tersebut, pelaku usaha harus menjelaskan tentang penanaman modal yang dilakukannya. Padahal, jika kita menilik karakteristik kegiatan usaha hulu migas, nampak bahwa kegiatan usaha hulu minyak dan gas bumi melalui PSC sebenarnya bukan merupakan kegiatan penanaman modal namun lebih merupakan perjanjian pemborongan, karena investornya tidak memiliki aset apapun, selain itu investornya (dalam hal ini BU / BUT) telah jelas-jelas disebut sebagai kontraktor.

e. NIB tidak membutuhkan PSC

Pasal 24 PP 24/2018 mengatur tentang Nomor Induk Usaha (NIB) yang dikeluarkan oleh lembaga OSS setelah melakukan pendaftaran. Ketentuan NIB ini cocok untuk suatu perusahaan yang akan didirikan dan akan masuk dalam kegiatan usaha hulu minyak dan gas bumi, namun harus diingat bahwa untuk masuk kegiatan usaha hulu minyak dan gas bumi sebelum masuk pada izin komersial atau izin operasional ada tender wilayah kerja dan kontrak kerja sama (PSC) dulu dan untuk ikut dalam tender WK maupun tanda tangan PSC tidak dibutuhkan NIB.

\section{Rekomendasi Untuk Memperbaiki Perizinan Migas Kedepan Termasuk Setelah Dikeluarkannya UU Cipta Kerja Dan PP Perizinan Berbasis Resiko}

Salah satu upaya pemerintah untuk meningkatkan investor dan menyelesaikan permasalahan perizinan, termasuk perizinan di hulu migas adalah 
dengan dikeluarkannya UU Cipta Kerja. ${ }^{48}$ Gagasan Rancangan UndangUndang Cipta Kerja (RUU Cipta Kerja) muncul sebagai respon pemerintah atas rendahnya tingkat investasi yang berakibat pada pelambatan pertumbuhan ekonomi. ${ }^{49}$ Terkait perizinan, pemerintah kemudian mengeluarkan Peraturan Pemerintah Nomor 5 Tahun 2021 tentang Penyelenggaraan Perizinan Berusaha Berbasis Risiko ("PP No. 5 Tahun 2021") yang mengganti PP OSS. Implikasi atas perubahan tersebut adalah bahwa saat ini pengaturan kegiatan usaha menitikberatkan pada aspek pengawasan alih-alih perizinan sebagaimana konstruksi lama dalam PP OSS. ${ }^{50}$ Lebih lanjut, dikeluarkan pula Peraturan Badan Koordinasi Penanaman Modal Nomor 4 Tahun 2021 tentang Pedoman dan Tata Cara Pelayanan Perizinan Berusaha Berbasis Risiko dan Fasilitas Penanaman Modal (“PerBKPM No. 4 Tahun 2021”) yang pada pokoknya peraturan perundang-undangan di atas mengatur bahwa perizinan berusaha dilakukan berdasarkan penetapan tingkat risiko dan peringkat skala kegiatan usaha.

Berdasarkan Pasal 4 PP No. 5 Tahun 2021, dalam memulai kegiatan usaha, pelaku usaha wajib persyaratan dasar perizinan berusaha; dan/atau perizinan berusaha berbasis risiko. Dalam hal ini, yang dimaksud dengan persyaratan dasar perizinan berusaha sebagaimana diatur dalam Pasal 5 PP a quo meliputi:

a) Kesesuaian kegiatan pemanfaatan ruang (KKPR);

b) Persetujuan Lingkungan;

c) Persetujuan Bangunan Gedung (PBG);

d) Sertifikat Laik Fungsi (SLF)

Adapun ketentuan lebih lanjut, termasuk diantaranya tata cara permohonan maupun proses penerbitan hal-hal di atas diatur lebih lanjut dalam PerBKPM No. 4 Tahun 2021. Berdasarkan kedua aturan tersebut, secara singkat perbandingan perizinan hulu migas yang diperlukan adalah sebagai berikut:

48 Mailinda Eka Yuniza, Melodia Puji Inggarwati, dan I Wayan Bhayu Pratama, "Business Licensing Issues Under the Indonesian Omnibus Law Bil," International Journal of Innovation, Creativity $\begin{array}{llllll}\text { and } & \text { Change } & 14, & \text { no. } & 9 & \text { (2020): }\end{array}$ https://www.ijicc.net/images/Vol_14/Iss_9/14949_Yuniza_2020_E1_R.pdf.

49 Admin, "Global Economic Prospects June 2020," World Bank, 2020, https://www.worldbank.org/en/publication/global-economic-prospects.

50 "Lampiran III Peraturan Pemerintah Nomor 5 Tahun 2021 tentang Penyelenggaraan Perizinan Berusaha Berbasis Risiko" (2021). 
Perbandingan Perizinan Berusaha Sebelum dan Sesudah UU Cipta Kerja

\begin{tabular}{|c|c|c|c|}
\hline No. & Kegiatan Usaha & Pra-UU Cipta Kerja & Pasca-UU Cipta Kerja \\
\hline 1. & $\begin{array}{l}\text { Pertambangan } \\
\text { Minyak Bumi } \\
\text { [KBLI 06100] }\end{array}$ & $\begin{array}{l}\text { 1. } \text { Izin Lingkungan; } \\
\text { 2. Izin PPLH; } \\
\text { 3. Izin Lokasi; } \\
\text { 4. Izin Mendirikan } \\
\text { Bangunan; } \\
\text { 5. Sertifikat Laik } \\
\text { Fungsi; }\end{array}$ & $\begin{array}{l}\text { 1. KKPR; } \\
\text { 2. Persetujuan } \\
\text { Lingkungan; } \\
\text { 3. Persetujuan Bangunan } \\
\text { Gedung; } \\
\text { 4. Sertifikat Laik Fungsi; } \\
\text { 5. NIB; } \\
\text { 6. Izin (Kontrak Kerja } \\
\text { Sama) }\end{array}$ \\
\hline 2. & $\begin{array}{l}\text { Pertambangan Gas } \\
\text { Alam } \\
\text { 06201] }\end{array}$ & $\begin{array}{l}\text { 1. Izin Lingkungan; } \\
\text { 2. Izin PPLH; } \\
\text { 3. Izin Lokasi; } \\
\text { 4. Izin Mendirikan } \\
\text { Bangunan; } \\
\text { 5. Sertifikat Laik } \\
\text { Fungsi; }\end{array}$ & $\begin{array}{l}\text { 1. KKPR; } \\
\text { 2. Persetujuan } \\
\text { Lingkungan; } \\
\text { 3. Persetujuan Bangunan } \\
\text { Gedung; } \\
\text { 4. Sertifikat Laik Fungsi; } \\
\text { 5. NIB; } \\
\text { 6. Izin (Kontrak Kerja } \\
\text { Sama) }\end{array}$ \\
\hline 3. & \begin{tabular}{lr}
\multicolumn{2}{l}{ Aktivitas } \\
Keinsinyuran dan \\
Konsultasi & Teknis \\
YBDI & [KBLI \\
$71102]$ &
\end{tabular} & $\begin{array}{l}\text { 1. Izin Lingkungan; } \\
\text { 2. Izin PPLH; } \\
\text { 3. Izin Lokasi; } \\
\text { 4. Izin Mendirikan } \\
\text { Bangunan; } \\
\text { 5. Sertifikat Laik } \\
\text { Fungsi; } \\
\text { 6. Izin Survei }\end{array}$ & $\begin{array}{l}\text { 1. KKPR; } \\
\text { 2. Persetujuan } \\
\text { Lingkungan; } \\
\text { 3. Persetujuan Bangunan } \\
\text { Gedung; } \\
\text { 4. Sertifikat Laik Fungsi; } \\
\text { 5. NIB } \\
\text { 6. Sertifikat Standar } \\
\text { 7. Izin (Izin Survei } \\
\text { Umum) }\end{array}$ \\
\hline
\end{tabular}

Meskipun diatas kertas, kehadiran UU Cipta Kerja dan peraturan pelaksanaannya telah mengurangi jumlah perizinan yang harus dipenuhi oleh investor yang akan melakukan usaha di bidang industri hulu migas, pada praktiknya persoalan-persoalan yang timbul sebagai akibat diberlakukannya PP OSS, belum semuanya terselesaikan. Jumlah perizinan yang nampaknya berkurang, pada praktiknya tidak sesederhana tabel diatas, karena untuk mengeluarkan perizinan yang ada pada tabel, masih dibutuhkan persyaratan- 
persyaratan lainnya ditambah pula dengan fakta bahwa perijinan yang sebelumnya eksis di kementerian-kementerian sektoral juga masih harus dipenuhi oleh calon investor. Lebih lanjut, permasalahan-permasalahan yang dibahas akibat diberlakukannya PP OSS masih eksis dan belum bisa dijawab dengan lugas oleh UU Cipta Kerja dan peraturan pelaksanaannya. Oleh karena itu, kebutuhan untuk Peraturan Presiden yang dapat mengakomodir kondisi khusus hulu migas, menyederhanakan perizinan hulu migas secara menyeluruh dan memperkuat ODSP masih relevan.

\section{PENUTUP}

Kegiatan hulu migas memiliki karakteristik yang berbeda dan spesifik dibandingkan kegiatan usaha lainnya. Pada awal tahun 2020 SKK Migas membentuk One Door Service Policy (ODSP) untuk mendukung sistem OSS sebagaimana diatur dalam PP 24/2018. Sistem Pelayanan Perizinan Terintegrasi Secara Elektronik (OSS) tidak sesuai dengan kebutuhan dan karakter kegiatan usaha hulu minyak dan gas bumi, sehingga OSS tidak bisa diharapkan untuk menjadi solusi bagi penyelesaian kerumitan perizinan Kegiatan Usaha Hulu Minyak dan Gas Bumi. Setelah dilakukan inventarisasi dan mapping perizinan, nampak bahwa antara satu peraturan belum sinkron dengan aturan lainnya, salah satunya yakni PP 24/2018 yang belum menjadikan UU 30/2014 sebagai rujukan. Untuk menyelesaikan permasalahan-permasalahan tersebut, perlu ada perubahan terkait PP 24/2018 khususnya yang menyangkut kegiatan usaha hulu migas. Perubahan tersebut dapat berupa penggunaan istilah "penetapan" dalam menggantikan "izin", penggunaan sistem klasterisasi sebagaimana dibuat di OSDP SKK Migas. Perubahan yang penting dan bersifat teknis diatur dalam peraturan presiden yang dapat menghapus ego-sektoral dengan mengakomodir kondisi khusus hulu migas, menyederhanakan perizinan hulu migas secara menyeluruh dan memperkuat ODSP masih relevan.

\section{DAFTAR PUSTAKA}

Admin. "Eksplorasi Migas Minim, Indonesia Terancam Defisit Gas 2023." $\begin{array}{llll}\text { Migas Hulu Jabar } & 2020 .\end{array}$ https://www.migashulujabaronwj.co.id/eksplorasi-migas-minimindonesia-terancam-defisit-gas-2023.

—. "Global Economic Prospects June 2020." World Bank, 2020. https://www.worldbank.org/en/publication/global-economic-prospects.

Agung Pribadi. "Menteri ESDM: Cadangan Minyak Indonesia Tersedia untuk 9,5 Tahun dan Cadangan Gas 19,9 Tahun." Kementerian Energi dan Sumber Daya Mineral, 2021.

Bumi, Satuan Kerja Khusus Pelaksana Kegiatan Usaha Hulu Minyak dan Gas. "Alur Bisnis Migas." Humas SKK Migas, 2016. https://humasskkmigas.wordpress.com/2016/07/27/alur-bisnis-migas.

—. "Kejar 1 Juta BOPD, SKK Migas Launching ODSP." SKK Migas, 
2020. http://www.skkmigas.go.id/berita/kejar-1-juta-bopd-skk-migaslaunching-odsp.

Davidson, Jamie Seth. "The Demise of Indonesia's Upstream Oil and Gas Regulatory Agency: An Alternative Perspective." Contemporary Southeast Asia 37, no. 1 (30 April 2015): 109-33. https://doi.org/10.1355/cs37-1e.

Eka. “Menkeu: Indonesia Net Importir Minyak Sejak 2003.” Aktual.com, 2014. https://aktual.com/?p=106018.

Fitra, Safrezi. "Pelaksanaan Kegiatan Hulu Migas Masih di Bawah Target." Katadata.co.id, 2014. https://katadata.co.id/safrezifitra/energi/5e9a5707ca795/pelaksanaankegiatan-hulu-migas-masih-di-bawah-target\#sthash.BSDqMvSv.dpuf.

HS, Salim. Hukum Pertambangan di Indonesia. Jakarta: Raja Grafindo Persada, 2006.

Konsideran huruf b Undang-Undang Nomor 22 Tahun 2001 Tentang Minyak dan Gas Bumi (2001).

Kurniawan, Faizal. "Bentuk Perlindungan Hukum Terhadap Kekayaan Minyak dan Gas Bumi Sebagai Aset Negara Melalui Instrumen Kontrak." $\begin{array}{lllllll}\text { Perspektif 18, no. } 2013): & 2 & \text { (27 }\end{array}$ https://doi.org/10.30742/perspektif.v18i2.116.

Lubiantara, Benny. Ekonomi Migas Tinjauan Aspek Komersial Kontrak Migas. Jakarta: Grasindo, 2013.

Mahardika, Lorenzo Anugrah. "Implementasi Sistem OSS Masih Hadapi Sejumlah Kendala | Ekonomi." Bisnis.com, 2019. https://ekonomi.bisnis.com/read/20190911/9/1147045/implementasisistem-oss-masih-hadapi-sejumlah-kendala.

Nasir, Mohamad. "Potret Kinerja Migas Indonesia Kementrian Keuangan," n.d. https://www.kemenkeu.go.id/sites/default/files/potret kinerja migas indonesia.pdf.

Peraturan Pemerintah Nomor 35 tahun 2004 Tentang Kegiatan Usaha Hulu Minyak dan Gas Bumi (2004).

Peraturan Pemerintah Nomor 5 Tahun 2021 tentang Penyelenggaraan Perizinan Berusaha Berbasis Risiko (2021).

Peraturan Pemerintah Republik Indonesia Nomor 24 Tahun 2018 tentang Pelayanan Perizinan Berusaha Terintegrasi Secara Elektronik (2018).

Peraturan Presiden Nomor 36 tahun 2018 Tentang Perubahan Atas Peraturan Presiden Nomor 9 Tahun 2013 Tentang Penyelenggaraan Pengelolaan Kegiatan Usaha Hulu Minyak dan Gas Bumi (2018).

Peraturan Presiden Nomor 9 tahun 2013 Tentang Penyelenggaran Pengelolaan Kegiatan Usaha Hulu Minyak dan Gas Bumi (2013).

Pudyantoro, A Rinto. A to Z Bisnis Hulu Migas. Jakarta: Petromindo, 2017.

Putuhena, M. Ilham F. "Politik Hukum Pengelolaan Hulu Migas Pasca Putusan Mahkamah Konstitusi." Jurnal Rechts Vinding: Media Pembinaan Hukum Nasional 4, no. $2 \quad$ (31 Agustus 2015): 237. https://doi.org/10.33331/rechtsvinding.v4i2.22.

Radhy, Fahmi. "Rezim Perijinan Menghambat Produksi Migas." 
Kompasiana.com,

2014.

https://www.kompasiana.com/fahmy_radhi/54f9329aa33311ef048b488c/ rezim-perijinan-menghambat-produksi-migas.

Redi, Ahmad. "Dinamika Konsepsi Penguasaan Negara Atas Sumber Daya Alam.” Jurnal Konstitusi 12, no. 2 (20 Mei 2016): 401. https://doi.org/10.31078/jk12210.

Samsul, Inosentius. "Kontroversi PP No 24 Tahun 2018." Mediaindonesia.com, 2018. https://mediaindonesia.com/read/detail/175843-kontroversi-pp-no24-tahun-2018.

Setyadi, Didik S. Politik Hukum Dinamika Penerapan Hak Menguasai Negara Atas Sumber Daya Alam Minyak Gas Bumi. Surabaya: Sahabat Mandiri, 2017.

Setyadi, Didik Sasono, Deti Mulyati, dan Azeem Marhendra Amedi. "Forestry Borrow to Use Permit in Upstream Oil and Gas Activity: Ecology Governance, Development Administration, and Administration Law Perspective." Yuridika 36, no. 1 (1 Januari 2021): 39. https://doi.org/10.20473/ydk.v36i1.21420.

SKK Migas. "Menuju 1 Juta BOPD \& 12 BSCFD di 2030 melalui Kegiatan Masif, Agresif dan Efisien," 2020.

Soekanto, Soerjono. Penelitian Hukum Normatif: Suatu Tinjauan Singkat. Jakarta: Raja Grafindo Persada, 2014.

Sopha, Bertha Maya. "Kebutuhan-Dan-Ketersediaan-Gas-Alam-Indonesia.Pdf." Pusat Studi Energi, n.d. https://pse.ugm.ac.id/wp/wpcontent/uploads/Kebutuhan-dan-ketersediaan-gas-alam-Indonesia.pdf.

Sujatmoko, Emanuel, Mailinda Eka Yuniza, Deendarlianto -, Tutuko Ariadji, Rina Mardiana, Indrawati -, dan Franky Butar Butar. "The simplification of Upstream Oil and Gas Business license in Indonesia." Research, Society and Development 9, no. 2 (1 Januari 2020): e16921950. https://doi.org/10.33448/rsd-v9i2.1950.

Suryajaya, Bobby, Charles Lim, dan Budi Ibrahim. "SKK Migas Sistem Operasi Terpadu-Performance Evaluation for Secure Data Exchange for Oil and Gas Contractors." Advanced Science Letters 20, no. 1 (1 Januari 2014): 129-33. https://doi.org/10.1166/as1.2014.5248.

Tambunan, Maria R.U.D., dan Ginda Togatorop. "Dualisme Ketentuan Cost Recovery Sebagai Dasar Pungutan Negara Pada Industri Hulu Migas." Veritas et Justitia 7, no. 1 (28 Juni 2021): 56-90. https://doi.org/10.25123/vej.v7i1.3740.

Undang-Undang Nomor 22 Tahun 2001 Tentang Minyak dan gas Bumi (2001). Yuniza, Mailinda Eka, Melodia Puji Inggarwati, dan I Wayan Bhayu Pratama. "Business Licensing Issues Under the Indonesian Omnibus Law Bil." International Journal of Innovation, Creativity and Change 14, no. 9 (2020):

716-33. https://www.ijicc.net/images/Vol_14/Iss_9/14949_Yuniza_2020_E1_R.p df.

Yuniza, Mailinda Eka, Aicha Grade Rebecca, dan Rahmah Candrika Ramadhaniati. "A Necessity or A Premature Move? The Shift of 
Indonesian Production Sharing Contract in the Oil and Gas Industry." International Journal of Energy Economics and Policy 10, no. 4 (15 Mei 2020): 251-57. https://doi.org/10.32479/ijeep.9024.

Yuniza, Mailinda Eka, Marsudi Triatmodjo, dan Rizkia Evania. "Gas governance in Indonesia." The Journal of World Energy Law \& Business 9, no. 2 (April 2016): 124-34. https://doi.org/10.1093/jwelb/jww004.

Yuniza, Mailinda Eka, Adhika Widyaparaga, Rifky Wicaksono, dan Putu Shanti Krisnadevi. "Natural gas aggregation and the opportunity for synchronization under Indonesian law." The Journal of World Energy Law \& Business 9, no. 5 (6 Oktober 2016): 388-409. https://doi.org/10.1093/jwelb/jww021. 